\title{
DISTRIBUTION OF SOIL MITES AND COLLEMBOLANS UNDER PINE TREES IN RIYADH REGION, SAUDI ARABIA
}

\author{
M. S. Al-Khalifa and B. M. Bayoumi* \\ Zoology Department, College of Science, \\ King Saud University, Riyadh, Saudi Arabia
}

\begin{abstract}
Synopsis
Al-Khalifa, M. S. and B. M. Bayoumi (Zoology Department, College of Science, King Saud University, Riyadh, Saudi Arabia): Distribution of soil mites and collembolans under pine trees in Riyadh region, Saudi Arabia. Acta arachnol., 32 : 27-36 (1983).

The seasonal and vertical distribution of soil mites and collembolans under pine trees in four sites of different soils at Riyadh region were investigated. A total of 40 species of Acari and 6 species of Collembola have been identified. Seasonal and vertical differences in population density in the four sites were discussed.
\end{abstract}

\section{Introduction}

Soil mites and collembolans are considered the most important decomposers among the soil fauna. Much work has been done on these animals in various parts of the world. However, arid and semi-arid ecosystems have received scant attention from zoologists. This includes works published by EL-KIFL (1957), Moursi et al. (1971), KolKaIlA et al. (1971) and HAMmAD et al. (1975).

To our knowledge, the only ecological study on the population dynamics of soil arthropods in the Arabian Peninsula was done by HAmmad et al. (1980). The aim of the present article is to investigate the distribution and dynamics of soil mites and collembolan populations under the widely distributed pine trees, Tamarix nilotica L., in Riyadh region.

* Present address : Zoology Department, Faculty of Science, Tanta University, Tanta, Egypt. 


\section{The Sample Sites and Methods}

The study was conducted in four localities within the Riyadh region, representing communities dominated by pine trees, T. nilotica L. (Fig. 1). A brief description of the sampling sites is given below:

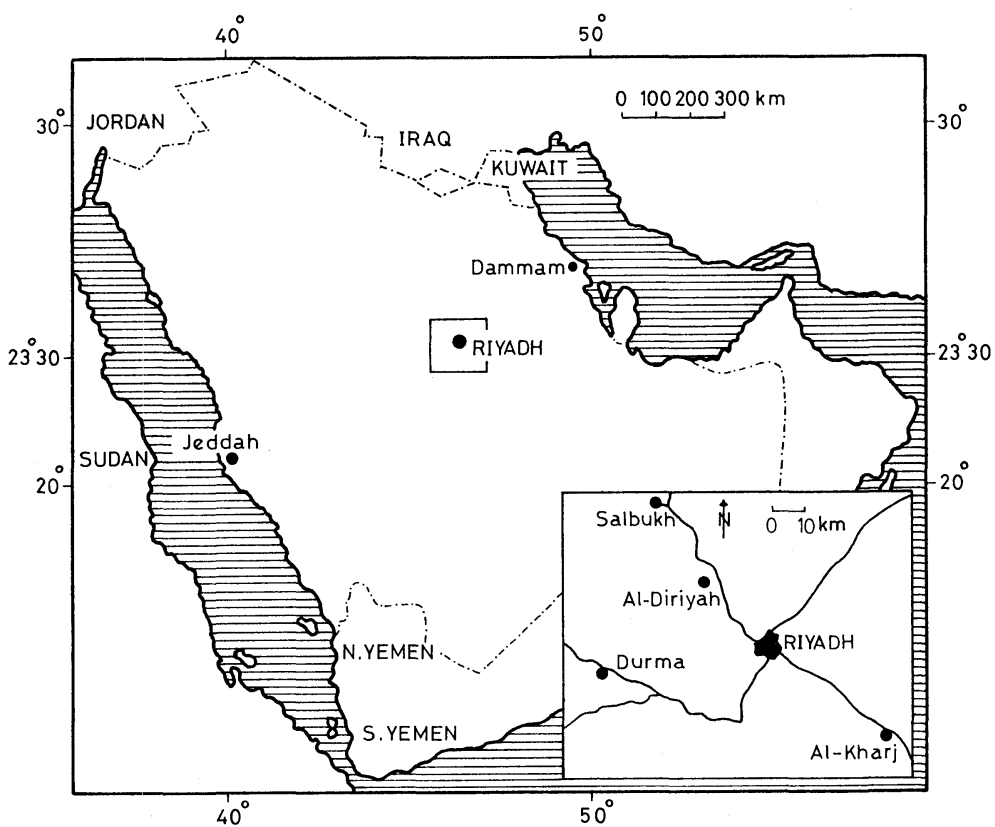

Fig. 1. Map of Saudi Arabia showing the sampling localities (inset: Riyadh region).

A) Al-Diriyah site: It is a five acres orchard, with pine trees occupying about half an acre, and the ground vegetation is dominated by Alfalfa (Medicago sativa L.). The orchard receives farmyard manure twice a year, in summer and in winter. The soil is sandy clay, with $\mathrm{pH}$ of about 7.3.

B) Salbukh site: This site is about one acre and was selected from a large orchard situated in Salbukh valley. Patches of Trifolium sp. are observed scattering at the sampling site during winter months. Farmyard manure is added in summer. The soil is sandy loam, with $\mathrm{pH}$ of about 7.1.

C) Al-Kharj site: It is a fallow soil, sampling was performed on a strip of land along the edge of an irrigation ditch. Pine leaf litter is usually abundant on the soil surface. The soil is sandy clay, with $\mathrm{pH}$ of about 7.6 . 
D) Durma site: It is a desert soil, of about two acres area adjacent to a large farm, with no ground vegetation. The soil surface is covered with a thin layer (about $1 \mathrm{~cm}$ thick) of pine leaf litter. This site was planted with Alfalfa for grazing camels one year before sampling. The soil is sandy, with $\mathrm{pH}$ of about 7.9 .

The sites were sampled on four occasions: June, October 1981; January and April 1982. Four soil samples per site were randomly collected on each occasion.

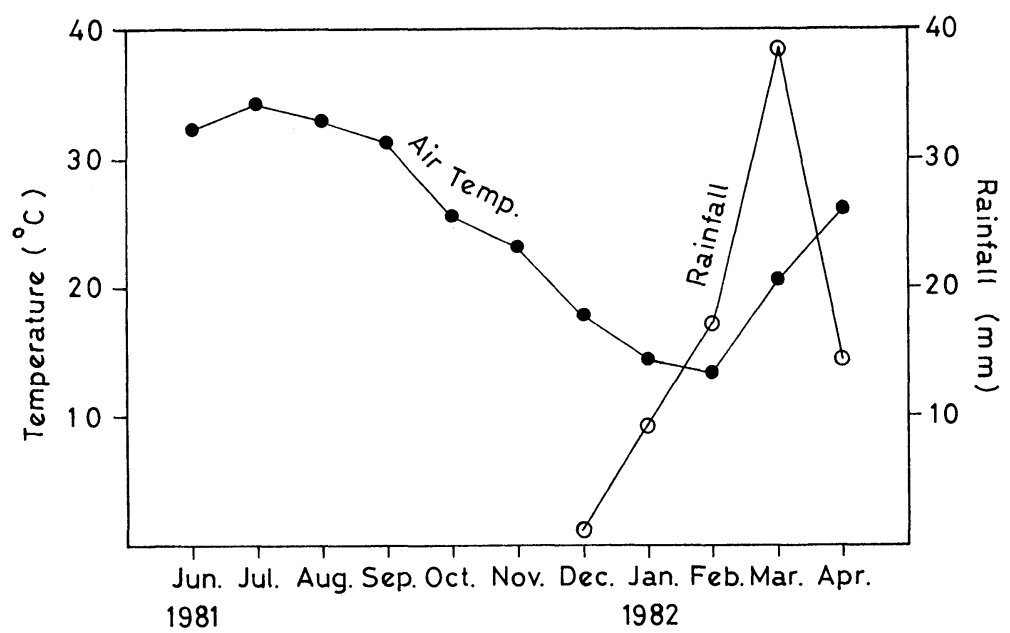

Fig. 2. Air temperature and rainfall during the investigation period.

Table 1. Mean moisture percentages, temperatures and organic matter contents of the tested soils.

\begin{tabular}{|c|c|c|c|c|c|c|c|c|c|c|c|c|c|}
\hline \multirow{2}{*}{ Month } & \multirow{2}{*}{$\begin{array}{c}\text { Depth } \\
\text { in } \\
\mathrm{cm}\end{array}$} & \multicolumn{4}{|c|}{ Soil Moisture $(\%)$} & \multicolumn{4}{|c|}{ Soil Temperature $\left({ }^{\circ} \mathrm{C}\right)$} & \multicolumn{4}{|c|}{ Organic matter $(\%)$} \\
\hline & & $\mathrm{A}$ & $\mathrm{B}$ & C & $\mathrm{D}$ & $\mathrm{A}$ & $\mathrm{B}$ & $\mathrm{C}$ & $\mathrm{D}$ & A & $\mathrm{B}$ & $\mathrm{C}$ & $\mathrm{D}$ \\
\hline June & $0-5$ & 2.5 & 3.1 & 2.4 & 1.0 & 24.0 & 23.0 & 28.0 & 21.8 & 3.0 & 2.4 & 1.1 & 0.8 \\
\hline 1981 & $5-10$ & 2.2 & 3.3 & 3.0 & 1.1 & 23.7 & 22.5 & 27.0 & 21.6 & 3.9 & 2.6 & 1.3 & 0.6 \\
\hline October & $0-5$ & 2.0 & 3.4 & 2.0 & 0.8 & 25.0 & 18.0 & 20.0 & 20.5 & 3.5 & 2.7 & 1.3 & 0.6 \\
\hline 1981 & $5-10$ & 2.3 & 3.5 & 2.2 & 0.7 & 22.5 & 18.0 & 19.0 & 19.5 & 3.6 & 2.9 & 1.5 & 0.7 \\
\hline January & $0-5$ & 3.2 & 4.2 & 2.5 & 2.0 & 17.0 & 12.0 & 16.0 & 10.0 & 3.1 & 2.9 & 1.6 & 0.7 \\
\hline 1982 & $5-10$ & 3.0 & 4.5 & 2.7 & 2.5 & 18.0 & 12.0 & 15.2 & 9.2 & 3.2 & 2.8 & 1.8 & 0.9 \\
\hline April & $0-5$ & 2.6 & 5.0 & 3.0 & 1.8 & 22.2 & 21.1 & 23.1 & 19.3 & 3.8 & 3.7 & 1.2 & 0.6 \\
\hline 1982 & 5-10 & 2.2 & 4.8 & 2.8 & 1.6 & 20.1 & 20.7 & 22.3 & 19.2 & 3.1 & 3.2 & 1.0 & 0.7 \\
\hline
\end{tabular}

A : Al-Diriyah B: Salbukh C: Al-Kharj D: Durma 
Animals were extracted from quadrangular metal cores $(10 \times 10 \times 5 \mathrm{~cm})$ using a modified Tullgren's funnel (BALOGH, 1958).

The physical properties of soil samples which were dealt with in the present investigation included: moisture content ( $\%$ of dry weight), soil temperature, organic matter \% (loss by ignition) and $\mathrm{pH}$ (see Table 1). Data for rainfall and air temperature during the investigation period are presented in Fig. 2.

\section{Results}

Faunistic composition: A total of fourty acarine species and six collembolan ones were identified from the four sites (Table 2). Among the acarine species, only four Cryptostigmata and two Prostigmata were recorded from all four sites. From the list presented in Table 2 it can be seen that Al-Kharj and Durma localities had 14 and 15 acarine species, and 1 and 2 collembolan ones, respectively; and were the poorest areas in this respect. Al-Diriyah locality supported the highest number of species of Acari and Collembola. There were 35 Acari found in this site, among them 23 Cryptostigmata, and 6 Collembola.

Seasonal variation in population density: It is evident from Table 3 that the highest population density of both Acari and Collembola occurred in Salbukh $\left(89,700 / \mathrm{m}^{2}\right.$ and $31,300 / \mathrm{m}^{2}$, respectively) and the lowest density of Acari was observed in Durma $\left(10,900 / \mathrm{m}^{2}\right)$. Collembolan population showed its lowest number $\left(4,300 / \mathrm{m}^{2}\right)$ in Al-Kharj. Generally, the collembolan populations were very much smaller than Acari in all sites examined.

Table 4 shows the break-down of the Acari data into groups. The Cryptostigmata comprised over $50 \%$ of all Acari in all sites. The highest percentage of mesostigmatid mites (24\% of the total Acari) was found in Salbukh, where most Collembola occurred.

Although in this present work the animals were sampled only seasonally, peaks and depressions in population numbers were evident. Fig. 3 shows the seasonal variation in the number of all species of mites and collembolans in the four tested soils. In all sites, the Collembola showed a peak of greatest abundance during spring. In Salbukh locality, however, an additional peak was observed in winter. In Al-Diriyah and Durma localities the mite populations, which were primarily dominated by the Cryptostigmata, showed two main peaks of abundance, one during winter and the other during spring. In Salbukh and AlKharj, however, the mite populations showed a similar fluctuation pattern, but 
Table 2. Faunal list of Acarina and Collembola for the four sample sites.

\section{A $\quad$ B $\quad$ C $\quad$ D}

S P E C I E S

A C A R I N A

CRYPTOSTIGMATA

Rhysotritia ardua (КосH)

Heptacarus ornatus BAyoumi et AL-Khalifa

Epilohmannia cylindrica cylindrica (BERLESE)

Epilomannia pallida aegyptica BAyoum et MAHUnKA

Nothrus biciliatus (KocH)

Microzetes auxiliaris GRANDJEAN

Tectocepheus velatus (MICHAEL)

Striatoppia niliaca (PopP)

Oppia bifidus Bayoumi et Al-Khalifa

Oppia clavipectinata (MichaEL)

Oppia foveolata (PAOLI)

Oppia mihelcici PÉREZ-IÑIGO

Oppia varians WALLWORK

Oppiella nova (OUdEMANs)

Oribatula tibialis (NICOLET)

Scheloribates fimbriatus africanus WALLWORK

Scheloribates laevigatus (KосH)

Scheloribates pallidulus (KосH)

Scheloribates saudicus BAyoumi et AL-Khalifa

Xylobates capucinus (BERLESE)

Rostrozetes foveolatus SELLNICK

Lamellobates hauseri aegypticus BAyoumI

Paralamellobates ceylanicus (Oudemans)

Galumna flabellifera HAMMER

Total number of cryptostigmatid species$$
+
$$

$+$

$++++$

$+++$

$+$

$+$

$+++$

$+$

$+$

$++\quad+$

$+++$

$++$

$+$

$++$

$+\quad+$

$+\quad+$

$++++$

$++++$

$+$

$+\quad+$

$++$

$+$

$+$

$+$

$+\quad+$

$\begin{array}{llll}23 & 12 & 9 & 8\end{array}$

\section{MESOSTIGMATA}

Prozercon kochi SELLNICK

Parazercon sarekensis WILLMANN

Sejus serratus (HALBERT)

Macrocheles apacus (KocH)

Macrocheles subbadius (BERLESE)

Pergamasus longicornis (BERLESE)

$\begin{array}{cccc} & + & & + \\ & + & & + \\ & + & & \\ + & & + & + \\ + & & & + \\ + & + & + & \\ 3 & 4 & 2 & 4\end{array}$


Table 2. (Contd.)

S P E C I E S

PROSTIGMATA

Raoiella indica HIRST

Cunaxa simplex EwING

Cunaxa capreolus (BERLESE)

Acropsis sollers ROHDENDORF

Spinibdella bifurcata ATYEO

Tydeus munsteri MEYER et RYKE

Eutetranychus afriasiaticus McGREGOR

Total number of prostigmatid species
A $\quad$ B $\quad$ C $\quad$ D

$++++$

$+++$

$++$

$+$

$+$

$+$

$++++$

$\begin{array}{llll}6 & 5 & 3 & 2\end{array}$

\section{ASTIGMATA}

Glycyphagus domesticus (De GeER)

Tyrophagus palmarum (OUDEMANS)

Schwiebia sp.

Total number of astigmatid species

$$
++
$$

$+\quad+$

Total number of acarine species

$\begin{array}{llll}3 & 1 & 0 & 1\end{array}$

$\begin{array}{llll}35 & 22 & 14 & 15\end{array}$

C OLLEMBOLA

Hypogastrura manubrialis (TULLBERG)

Hypogastrura armata (NICOLET)

Tomocerus minor (LUB.)

Seminuthrus viridis L.

Entomobrya sp.

$\begin{array}{llll}+ & + & + & \\ + & + & & + \\ + & & \\ + & + & & + \\ + & + & & \\ + & + & \end{array}$

Total number of collembolan species

+ indicates that species recorded on that sample site.

A: Al-Diriyah B: Salbukh C: Al-Kharj D: Durma

Table 3. Populations of soil Collembola and Acari (in thousands $/ \mathrm{m}^{2}$ ) of the four investigated localities. The data are the means and standard errors of 16 soil cores.

\begin{tabular}{lrrr}
\hline \multicolumn{1}{c}{ Site } & Collembola & \multicolumn{1}{c}{ Acari } & \multicolumn{1}{c}{ Total } \\
\hline Al-Diriyah & $15.5 \pm 1.18$ & $76.3 \pm 7.33$ & $91.8 \pm 8.51$ \\
salbukh & $31.3 \pm 2.13$ & $89.7 \pm 9.62$ & $121.0 \pm 11.75$ \\
Al-Kharj & $4.3 \pm 0.90$ & $33.7 \pm 5.11$ & $38.0 \pm 6.01$ \\
Durma & $8.4 \pm 2.71$ & $10.9 \pm 1.56$ & $19.3 \pm 4.27$ \\
\hline
\end{tabular}


Table 4. Soil Acari populations (in thousands $/ \mathrm{m}^{2}$ ) of the four investigated localities. The data are the means and standard errors of 16 soil cores, and the percentage of each suborder of the total Acari are given.

\begin{tabular}{cccccc}
\hline Site & Cryptostigmata & Mesostigmata & Prostigmata & Astigmata & Total Acari \\
\hline Al-Diriyah & $66.4 \pm 5.90$ & $2.6 \pm 0.42$ & $6.5 \pm 0.80$ & $0.8 \pm 0.21$ & $76.3 \pm 7.33$ \\
$\%$ & 87.02 & 3.41 & 8.52 & 1.05 & \\
Salbukh & $58.7 \pm 4.20$ & $21.7 \pm 3.00$ & $6.4 \pm 1.60$ & $2.9 \pm 0.82$ & $89.7 \pm 9.62$ \\
$\%$ & 65.44 & 24.19 & 7.13 & 3.23 & \\
Al-Kharj & $29.1 \pm 3.62$ & $3.7 \pm 1.05$ & $0.9 \pm 0.44$ & - & $33.7 \pm 5.11$ \\
$\%$ & 86.35 & 10.98 & 2.67 & & \\
Durma & $8.7 \pm 0.83$ & $1.3 \pm 0.45$ & $0.7 \pm 0.21$ & $0.2 \pm 0.07$ & $10.9 \pm 1.56$ \\
$\%$ & 79.82 & 11.93 & 6.42 & 1.83 &
\end{tabular}

with a third peak found in autumn.

In all sites the Cryptostigmata was most dominant during winter and spring. The Mesostigmata, Prostigmata and Astigmata did not show any seasonal fluctuation in all investigated localities, although the number of mesostigmatid mites in Salbukh showed an increase during autumn.

Vertical migration: The seasonal population changes in depth distribution are given in Fig. 3. In all sites and during the seasons investigated, cryptostigmatid mites were generally found to inhabit the $5-10 \mathrm{~cm}$ level of soil. However, during spring in Al-Diriyah, Al-Kharj and Salbukh, they were dominant in the $0-5 \mathrm{~cm}$ soil layer. The other suborders of Acari showed no significant changes in depth distribution in all sites.

Collembolans were rare in both layers of soil during summer in all localities, except in Salbukh where they were most abundant in the $0-5 \mathrm{~cm}$ level. During autumn and winter the collembolan population migrated downwards to the 5$10 \mathrm{~cm}$ depth in all localities. During spring, however, they were almost equally distributed in both layers of soil in Al-Diriyah and Al-Kharj, but there was a detectable upward migration in Salbukh and Durma.

\section{Discussion}

Many investigators have noticed that the suborder Cryptostigmata dominates other mite suborders. The same was also observed in the present study, where the number of cryptostigmatid species and individuals were found to be the largest among mite populations. The abundance of cryptostigmatid mites, especially in 


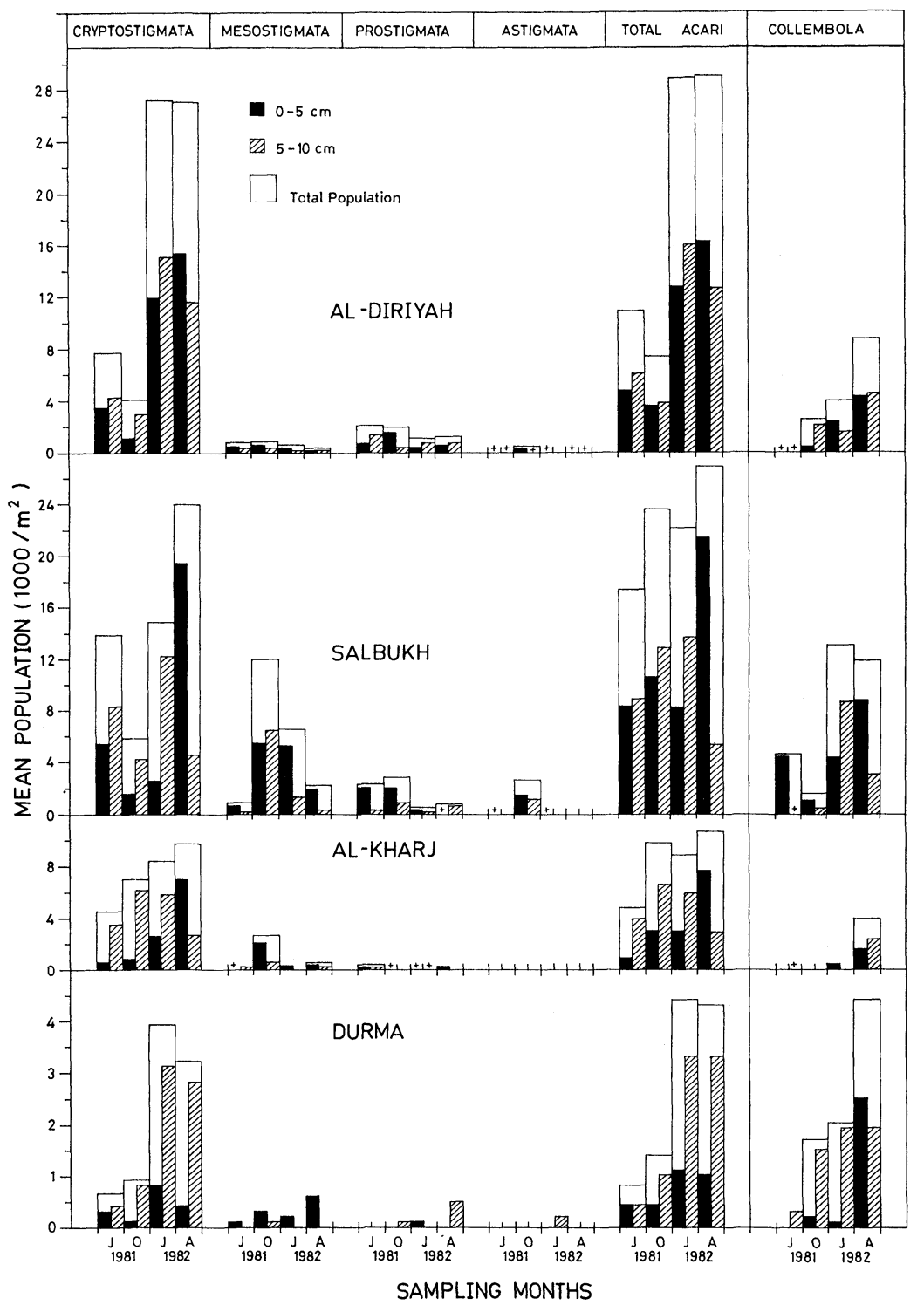

Fig. 3. Population dynamics of Acarine Suborders and Collembola in the four localities. ( + indicates that mean population is less than 200 ind. $/ \mathrm{m}^{2}$ ) 
Al-Diriyah locality, could be attributed to the rich organic matter content of the soil. This agrees with the finding of LoOTs and RYKE (1967) and HAMMAD et al. (1971) who reported that cryptostigmatid mites mostly dominate in soils that are rich in organic matter. A further support to this concept is the finding, in the present study, of a poor population density of these mites in Durma locality, where the organic matter content was the lowest.

In general, the nature of soil and its ground vegetation seem to highly influence the population density of Acari and Collembola. Sandy soils where ground vegetation is absent such as the one in Durma locality, for instance, were found to be unsuitable for either mites or collembolans.

A comparison between the population density estimates presented in this study with data obtained by other investigators in other arid ecosystems may prove to be difficult because of the different nature of soil and vegetation cover. The winter and spring peaks of acarine and collembolan populations observed in all examined sites were expected because of the optimum microenvironmental conditions of the soils, especially its moisture content and temperature at that time of the year. Similar population peaks were observed by KolKaILA et al. (1971) in their investigation of arthropods in some Libyan soils; and also by HAMmAD et al. (1980) under date-palm trees in the Eastern Province of Saudi Arabia- Furthermore, MADGE (1969) indicated that the number of invertebrates, in general, decreases drastically in the dry season as compared with the wet season in forest and savanna soils.

The vertical migration of soil mites and collembolans under arid conditions appears to be governed mainly by the soil temperature and its moisture content. The indication from the present study is that the animals prefer the more constant microenvironment in the deeper soil layer $(5-10 \mathrm{~cm}$ depth), especially during the dry summer period.

\section{References}

BALOGH, J., 1958. Lebensgemeinschaften der Landtiere, ihre Erforschung unter besonderer Berucksichtigung der zoozonologischen Arbeitsmethoden. Budapest-Berlin $560 \mathrm{pp}$.

- 1972. The Oribatid Genera of the World. Akad. Kiado, Budapest, $188 \mathrm{pp}$. $+71 \mathrm{pls}$.

EL-KIFL, A.H., 1957. The soil arthropod fauna of a farm at Giza, Egypt (parts I-III).

Bull. Soc. Ent. Egypt, XLI : 213-268.

Gisin, H., 1960. Collembolen Fauna Europas. Museum d' Histoire Naturelle, Geneve, 312 pp. Hammad, S., H. El-Nakhal, M. Ramadan, \& A. Wahadan, 1980. Seasonal variations 
in the population of soil arthropods and soil bacteria under date-palm trees at Al-Hassa region (Eastern Province, Kingdom of Saudi Arabia). Proc. Saudi Biol. Soc., 4 : 233244.

Hammad, S., A. Kolkaila, \& A. Makawi, 1971. Ecological studies on the arthropod fauna of certain Libyan soils. Acta Phytopath. Acad. Sci. Hung., 6(1-4) : 153-164.

Hammad, S., M. Nassar, A. Donia \& S. El-SawaF, 1975. Studies on the soil insect fauna and other arthropods. Part 1: Number and category of the soil animal fauna. Bull. Soc. Ent. Egypt, LIX : 201-206.

Kolkaila, A., A. Makawi \& S. Hammad, 1971. Studies on the arthropods and microorganisms of some Libyan soils: Soil arthropods and microorganisms from under four fruit trees. Libyan Jour. Sci., 1:21-30.

Loots, G.C. \& P.A. J. Ryke, 1967. The ratio Oribatei: Trombidiformes with reference to organic matter content in soils. Pedobiologia, $7: 121-124$.

Madge, D. S., 1969. Litter disappearance in forest soil and savanna. Pedobiologia, $9: 288$ 299.

Moursi, A. A., A. A. Hussein \& E. M. Kassem, 1966. Soil insects and mites of date-palm orchards in Iraq. Bull. Soc. Ent. Egypte, L: 71-76. 